\title{
Finite Element Analysis of Brake Shoe Based on ANSYS Workbench
}

\author{
Bin Zheng ${ }^{1,2}$, Jingdong Zhang ${ }^{1,2}$ and Wenwu Liu ${ }^{1,2}$ \\ ${ }^{1}$ School of Transportation and Automobile Engineering, Panzhihua University, Panzhihua, Sichuan 617000, China \\ ${ }^{2}$ Institute of Automobile Engineering Technology of Panzhihua, Panzhihua, Sichuan 617000, China
}

\begin{abstract}
This paper takes brake shoe of drum brake as the object of study. The three dimensional model of brake shoe is established by using CATIA software. It is calculated that the driving force of the cam to brake shoe and the spring of brake shoe back position. Based on this, the static analysis of brake shoe structure is carried out by using ANSYS Workbench software, the stress and deformation of brake shoe are obtained under the static load condition. The structure of brake shoe is optimized and the maximum stress of the optimized brake shoe is reduced by $30.88 \%$, which provides a theoretical basis for the structural design and optimization of brake shoes.
\end{abstract}

Keywords—brake shoe; static analysis; finite element analysis

\section{INTRODUCTION}

Brake system of the care is an important part of the safety of the car. At present, most of the cars are used drum brakes. The drum brakes have a large braking force due to the large contact surface, but the drum brakes are subject to problems such as stress concentration during use. This is the main problem that restricts the development of drum brakes [1].

Aiming at the research on the mechanical properties of drum brake shoe, more and more scholars at home and abroad have studied it. Wang Jizhong calculated and compared the structural strength of brake shoe before and after the brake pressure was increased. After the brake pressure was improved, the strength of the shoe was insufficient, and the root of the roller shaft was easily damaged [2]. The design of brake shoe was improved, and the structural scheme which could meet the requirement of use was obtained. Zhang jianhui introduces the APDL language under the ANSYS environment in order to simulate the positive pressure and the corresponding friction force. The stress field distribution of brake shoe is obtained [3]. Zhang Shuaipeng proposed a topological optimization method of brake shoe on the basis of modal analysis. The lightweight design of the brake is achieved and it brings the direct economic benefits [4]. Liu Ligang takes brake shoes, brake drum and friction lining as a whole. Therefore, the brake process is carried out the finite element analysis in a more realistic simulation. The pressure distribution, braking torque, stress distribution and deformation of the brake are predicted.

The above literatures are devoted to the study and analysis of the mechanical properties of brake shoe in the braking state, but the researches on brake shoe in the static load state are less [5]. Therefore, the paper takes brake shoe as the research object, and calculates the stress distribution of brake shoe under static load conditions, which lays the foundation for practical application.

\section{Brake Shoe Finite Element Model}

\section{A. Build a Geometric Model}

The type of brake is called as a collar-type brake, belonging to the traditional drum brakes. The brake drum mainly includes the brake drum, brake shoes and friction lining. The structure of drum brakes is shown in Figure 1.

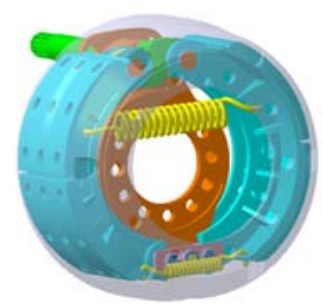

FIGURE I. STRUCTURE OF DRUM BRAKE

Geometric model of brake shoe is established by using CATIA software. The static load condition of brake shoe is mainly for brake shoe force, but it is not in contact with the brake drum. Brake shoe model should be considered for proper simplification before importing into ANSYS via the data interface.

The method of simplified structure model is as following principles.

1) Simplify the small corners and chamfer, ignore small features in the structure, such as grooves and holes.

2) Neglect all the small holes in brake shoe and the friction lining riveting[6].

Then, the simplified three-dimensional geometric model of brake shoe is shown in Figure 2.

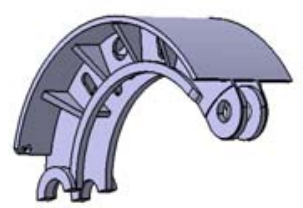

FIGURE II. SIMPLIFIED 3D GEOMETRIC MODEL OF BRAKE SHOE 


\section{B. Static Load Conditions}

Static load conditions of brake shoes are not subject to change in the external force and brake shoe itself. Therefore, conditions of brake shoe do not change with time, that is, brake shoe does not have the acceleration. F1 makes the action that brake shoe rotates along the support pin to open, but not yet in contact with the brake drum. At the same time, brake shoe bears the tension of return spring, gravity and other forces. Figure 3 is a schematic diagram of the force that brake shoe is opened by the urging force of the cam but not yet in contact with the brake drum.

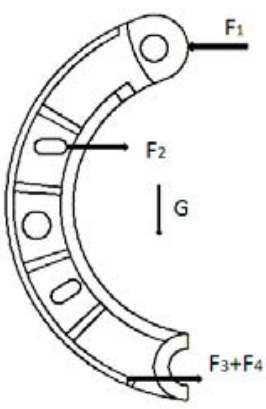

FIGURE III. STATIC LOAD DIAGRAM OF BRAKE SHOE

\section{Definition of Material Property}

Material of brake shoe is commonly used ductile iron with high strength and good toughness. This brake shoe is used of QT500-7 that the material properties are shown as Table 1.

TABLE I. MATERIAL PROPERTIES OF QT500-7

\begin{tabular}{cccc}
\hline Density $\mathrm{kg} / \mathrm{m}^{3}$ & Young's modulus elastic ratio $/ \mathrm{Pa}$ & Poisson's ratio & intensity of tension tensile strength / MPa \\
\hline 7000 & $1.62 \mathrm{e}+11$ & 0.293 & 500 \\
\hline
\end{tabular}

\section{Brake Shoe Model Grid Division}

The tetrahedron element is used for establishing finite element model of brake. The advantage is that it can be quickly and automatically generated mesh. Because of the tetrahedral mesh with isometric characteristics, it will lead to a rapid increase in the number of grids. The grid cell size is $4 \mathrm{~mm}$, the number of grid nodes is 116661 , and the total number of grid cells is 65186 . The finite element model of brake shoe is shown in Figure 4.

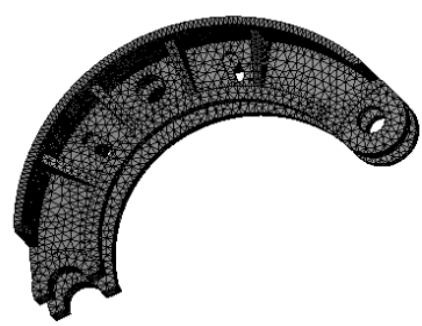

FIGURE IV. FINITE ELEMENT MODEL OF BRAKE SHOE

\section{MECHANICS ANALYSIS, LOAD AND CONSTRAINT}

\section{A. Mechanics Analysis}

The type of brake is corresponding to the model for a medium-sized truck, brake shoe cam can be based on the actual pressure that the brake pipe pressure sensor is used to obtain the pressure of the brake pipe $\mathrm{P}$.

where $\mathrm{P}$ is generally not more than $12 \mathrm{Mpa}$ and $\mathrm{d}$ is diameter of brake wheel cylinder. Diameter of brake wheel cylinder is $37.2 \mathrm{~mm}$, so the driving force P1 on the brake collar is

$$
P_{1}=\frac{\pi \mathrm{d}^{2}}{4} \times P=\frac{3.14 \times 37.2^{2}}{4} \times 11=11949.5 N
$$

Spring force of the spring can be calculated according to Hooke's law, the formula is

$$
F=K \times \Delta X
$$

where $\boldsymbol{K}$ is the spring stiffness factor and $\boldsymbol{\Delta} \boldsymbol{X}$ is the tensile length. Stiffness coefficient $K$ of tension spring can be calculated according to following formula.

$$
K=\frac{\text { diameter } \times 1000}{C^{3} \times \text { work cycles }}=\frac{4 \times 1000}{2^{3} \times 12}=42 \mathrm{~N} / \mathrm{mm}
$$

where $\mathrm{C}$ is diameter that medium divided by diameter of spring. Number of work cycles is that total numbers of turn of spring subtract two. So the spring tension value is calculated as:

$$
F=K \times X=42 \times 20=840 N
$$

Similarly, the calculated value of the return spring is $1296 N$.

\section{B. Load and Constraints}

The boundary condition of brake shoe is relatively complicated and the constraint is simplified according to the stress condition of the static load. The applied load and the correctness of the constraint have great influence on the results, and the braking force is more complicated. In order to make the support pin of brake shoe only rotate along its fixed axis, it can be supported the semi-circular surface of the support pin to add a rotation pair. The urging force of $\mathrm{P} 1$ is $11949.5 \mathrm{~N}$. The formula is based on the above formula. Brake shoe is also subjected to the pulling force of return spring and the load and restraint of brake shoe are shown in Figure 5. 


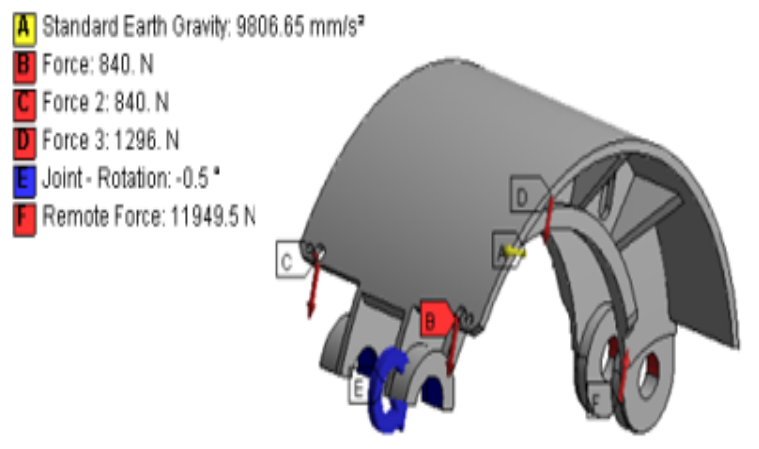

FIGURE V. LOAD AND CONSTRAINT OF BRAKE SHOE

\section{RESUlts DisCUSSION}

\section{A. Deformation Analysis of Brake Shoe}

The figure 6 gives the overall deformation of brake shoe. It can be seen that maximum deformation position of brake shoe occurs at the cam actuating force application end. Due to the urging force of cam, the maximum deformation of the load applied end reaches $4.06 \mathrm{~mm}$, which is mainly related to the working environment of brake shoe. As there are some constraints in support pin hole, it is relatively small deformation.

Based on the results of finite element analysis, a certain amount of deformation should be reserved in the structural optimization design stage of brake shoe to avoid the influence of local deformation on the braking performance.

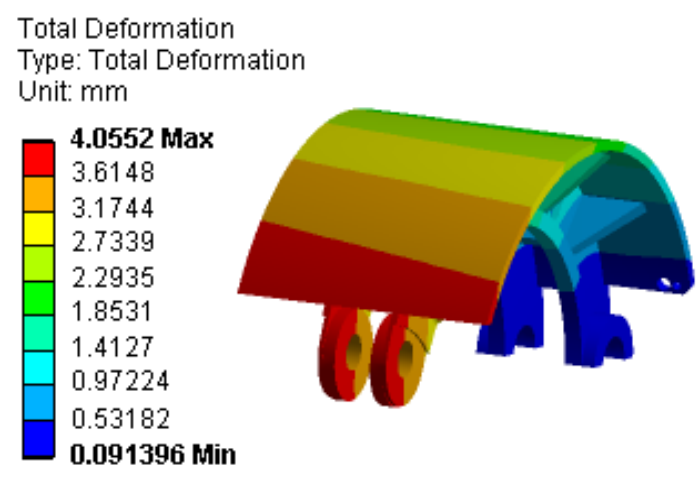

FIGURE VI. OVERALL DEFORMATION OF BRAKE SHOE

\section{B. Stress Analysis of Brake Shoes}

Figure 7 shows the equivalent stress cloud diagram of brake shoe. It can be seen from that the maximum stress of brake shoe is $418.09 \mathrm{MPa}$ and intensity of tension tensile strength of QT500-7 is 500MPa. While the safety factor is 1.5 , the allowable stress is 334Mpa. Results of the maximum stress are greater than the allowable stress value of the material. It is prone to fatigue damage. Because of support pin can rotate along fixed axis, its stress is relative less. At the same time, the maximum stress of brake shoe is gradually decreasing from the back outside to the inside of brake shoe.

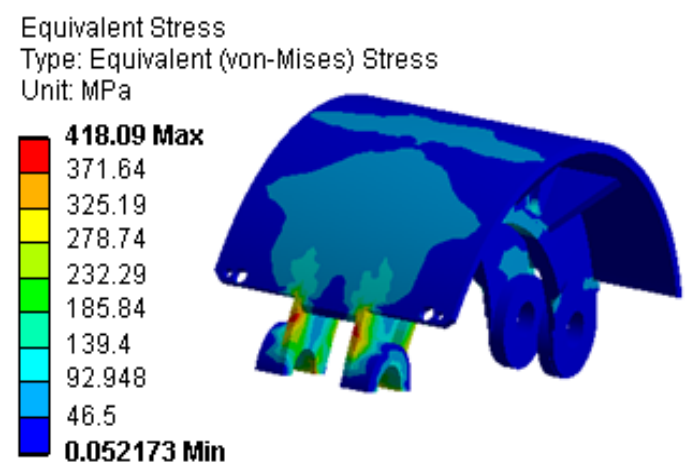

FIGURE VII. EQUIVALENT STRESS OF BRAKE SHOE

\section{IMPROVEMENT OF BRAKE SHOE STRUCTURE}

In order to ensure the performance of brake shoe, it is necessary to reduce the stress concentration of brake shoe during the design process and increase its service life. The improvement method is that by thickening and chamfering of brake shoe main beam. Dimension of main beam of brake shoe thickens10milimeters. The improved structure of brake shoe model is shown in Figure 8.

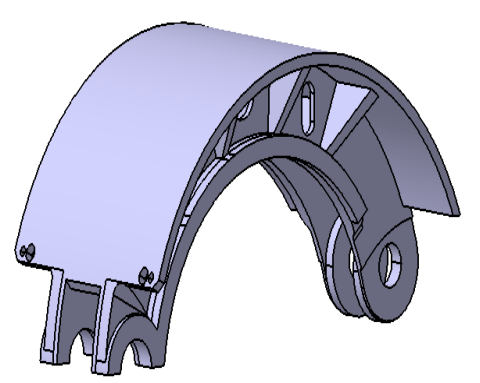

\section{FIGURE VIII. IMPROVED MODEL OF BRAKE SHOE}

After improvement of structure, the finite element analysis of brake shoe is carried out again and the stress cloud is shown in Figure 9. It can be seen that the stress cloud of brake shoe is basically the similar, but maximum stress is reduced from original $418.09 \mathrm{MPa}$ to $288.97 \mathrm{MPa}$, which is reduced by $30.88 \%$. It is shown that after stress concentration of brake shoe is decreased by improvement.
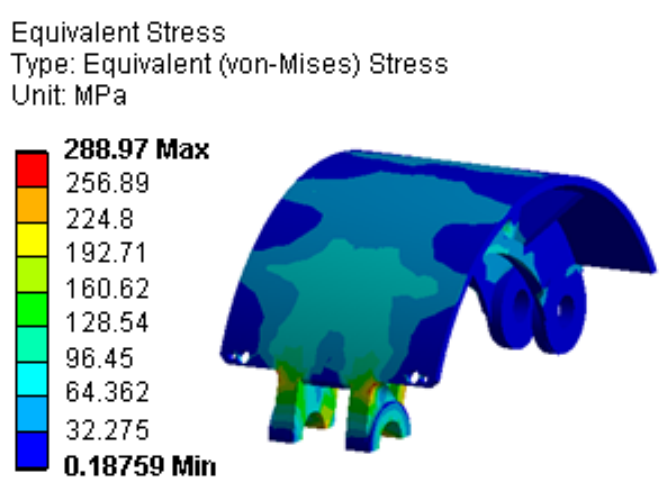

FIGURE IX. STRESS CLOUD OF IMPROVEMENT BRAKE SHOE 


\section{CONCLUSION}

Based on the calculation of brake shoe force under static load, the finite element analysis of brake shoe under static load is carried out. By analyzing the deformation and stress cloud of brake shoe, it can see that structure of brake shoe is not very reasonable. Maximum deformation of brake shoe reaches $4.06 \mathrm{~mm}$ and maximum stress value of brake shoe is greater, which would damage structure of brake shoe. Structure of brake shoe is improved by thickening, chamfering main beam of brake shoe. Maximum stress of brake shoe is reduced from original $418.09 \mathrm{MPa}$ to $288.97 \mathrm{MPa}$, which is reduced by $30.88 \%$.

\section{ACKNOWLEDGEMENT}

This research was financially supported by Educational Commission of Sichuang Province Key Project (Grant No. 18ZA0293) and $\mathrm{PhD}$ Research Startup Foundation of Sichuang Panzhihua University(Grant No. BSYJS2017-001).

\section{REFERENCES}

[1] MA Sheng-li, WANG Ye, ZHANG Li-ping et al. Study on temperature distribution of multi-disc disc brake of shearer [J]. Coal Science and Technology, 2016, 35 (7): 229-231.

[2] Wang Jizhong, Wang Zengwen, Yang Zhicheng et al. Finite element analysis of brake shoe brake shoe[J]. Manufacturing Automation, 2015, 37(5): 106-108.

[3] Zhang Jianhui, Yan Yunbing, Ma Xun. Finite element analysis of drum brake shoe based on ANSYS Workbench and APDL [J]. Journal of Hubei Institute of Automotive Technology, 2011, 25(3): 13-15.

[4] Zhang Shuaipeng, Zhang Anning. Modal analysis and topology optimization of drum brake shoe based on ANSYS Workbench [J]. Coal Mine Machinery, 2016, 37(4): 151-152.

[5] Liu Ligang, Wang Xuelin. Finite element analysis of drum brakes [J]. Special Purpose Vehicle, 2003, (3): 21-23.

[6] Sydney G. Roberts and Terry D. Day. Integrating design and virtual test environments for brake component design and material selection, SAE 2000-01-1294.

[7] Xuanfeng Wang, Yingchun Liang, Chaosheng Huang, et al. Research on dynamic performance of drum brake. SAE 2007-01-3673. 